\title{
Security Perceptions of the Tourists Visiting Alanya According to Their Home Country
}

\section{Alanya'yı Ziyaret Eden Yabancı Turistlerin Ülke Gruplarına Göre Güvenlik Algılarının Analizi}

\author{
Asst. Prof. Dr. Muharrem Aksu (Alanya Alaaddin Keykubat University, Turkey) \\ Asst. Prof. Dr. Ali Rıza Aktaş (Alanya Alaaddin Keykubat University, Turkey) \\ Asst. Prof. Dr. Mehmet Özer Demir (Alanya Alaaddin Keykubat University, Turkey) \\ Asst. Prof. Dr. Faruk Kerem Şentürk (Düzce University, Turkey)
}

\begin{abstract}
In today's world there exists severe competition in all sectors, in tourism sector as well. That's why countries with successful destinations consider tourism security concept as part of the tourism concept in order to maximize tourist demand. On the other hand, tourism security and risk perception of a destination is one of the principal components of destination image. Tourism security seems to be the most important appealing factor of the demand. The aim of the study is to research the risk perception differences between the tourists' home countries when grouped (North European, East European, Middle European, West European and the others). According to Data set from 500 respondents different countries visiting Alanya is analyzed, findings suggest that there exits differences among the places (beach, recreation center, public transportation etc.) and factors (traffic, terror, day and night treks, mugging, theft etc.) effecting respondents' risk perceptions.
\end{abstract}

\section{Giriş}

Günümüzde her geçen gün uluslararası turistlerin sayısının artması turizm sektörüne yönelik yatırımların önemini ortaya koymaktadır. Turizm talebinin yaratılmasına yönelik sektöre ciddi yatırımlar yapılmakta; bu yatırımların değer yaratabilmesi ise turistlerin destinasyon bölgesini ziyaret etmesi ile mümkün olabilmektedir. Turistlerin destinasyonu ziyaret etme kararı, karmaşık bir karar-alma sürecinden sonra olgunlaşmaktadır. Kararalma sürecinde destinasyon seçimi ise belirli değişkenlerin etkisi altında gerçekleşmektedir. Bu değişkenlerinden biri de güvenliktir. Özellikle destinasyonun güvenliği uluslararası turistlerin en çok hassas oldukları faktörlerden biri olarak karşımıza çıkmaktadır. Destinasyonun imajı, güvenlik açısından olumsuz ise turistler genellikle o bölge hakkında olumsuz algıya sahip olmakta ve tatil tercihlerini genellikle değiştirebilmektedirler. Gerçekten de turizm sektörünün en küçük risk faktörlerinden kolaylıkla etkilenebilen kırılgan bir sektör olması, emniyet ve güvenliğin önemini daha da arttırmaktadır. Kabul edilebilir risk seviyesinin üstünde bir risk algılaması, yani emniyetsizlik ya da güvensizlik durumu, ilgili destinasyona talebi düşürebilmektedir. Turistlerde oluşan olumsuz destinasyon imajı, turizm yatırımlarının atıl kalmasına neden olmaktadır. Özellikle ekonomik ve politik ve ekonomik istikrarsızlık, suç, hastalık, doğal felaketler gibi turistin seyahat tatminini engelleyebilecek problemlerin ilgili destinasyonlarda var olması, turizm talebini etkileyebilmektedir. Bahsedilen riskler turistler tarafından farklı düzeylerde algılanabilmektedir. Farklı düzeylerde oluşan alg1 ise, çoğunlukla turistlerin çeşitli sosyo-demografik özelliklerinden kaynaklanabilmektedir. Sosyo-demografik özellikler içerisinde milliyet faktörü de literatürde önemli bir değişken olarak görülmektedir. Bu bağlamda turistlerin tatil esnasında ya da öncesinde ne hissettiğini anlamak, ziyaretçilerin kişisel güvenlik algılarını tespit etmek açısından şarttır. Yabancı turistlerin riskten kaynaklı güvenlik algısı, onların kendi içsel güvenlik ihtiyaçlarını anlama ve tatmin etme açısından da kritik öneme sahiptir.

Araştırmamızda Alanya'yı ziyaret eden yabancı turistlerin özellikle ülke gruplarına göre güvenlik algı düzeylerinin farklı olup olmadığı sorgulanmıştır. Çalışmada öncelikle turizm güvenlik ilişkisi, bu ilişkide belirleyici unsur olan risk algısı ve milliyetlere göre güvenlik algı düzeylerinin farklılığı teorik olarak incelenmiş ve bulgular kısmında ise Alanya'nın güvenlik algısının milliyetlere göre farklılı̆̆ irdelenmiştir.

\section{Turizm ve Güvenlik}

Turizmde politik güvenlik, ekonomik istikrar, sağlık, hijyen, turist mahremiyeti, suç ve yasal koruma gibi birbirine bağlı faktörleri kapsayan emniyet ve güvenlik, karmaşık ve çok boyutlu kavramlardır. Emniyet ve güvenlik, konaklama sektöründe huzurlu bir tatilin ve turizm destinasyonuna talebin en temel unsuru olarak görülmektedir (Kovari ve Zimanyi, 2011). Ziyaretçilerin seyahat kararlarını alırken güvenlik ve emniyet algısı, önemli bir belirleyici olduğu çalışmalarda vurgulanmaktadır (Rittichainuwat ve Chakraborty, 2009; Çetinsöz ve Ege, 2013). Araştırmalarda doğal afetler, bulaşıcı hastalıklar, güvenli olmayan seyahat olanakları, suç, şiddet ve siyasi istikrarsılık gibi kişisel güvenlikle doğrudan ilgili olan güvenlik risklerinden etkilenen birçok turizm aktivitesi tanımlanmıştır. Turistlerin bahsedilen risklerden kaynaklı tatil bölgesini güvensiz ve tehdit edici 
hissettiğinde, o yere yönelik olumsuz bir izlenim geliştireceğini yani o bölgenin tehlikeli bir yer olarak algılanacağını ve dolaylı olarak da o bölgede turistlerin sayısını azalacağını göstermektedir (Flicker ve Gardner, 2002; Anuar ve diğ., 2010; Amir ve diğ., 2015:124,126). Bu nedenle emniyet ve güvenliğin tüm turizm destinasyonlarının gelişimi için oldukça önemli boyutları olduğu ortadadır (Amir ve diğg., 2015:124). Özellikle destinasyonda turistlere yönelik suçların artması, hatta arttığı algısının ortaya çıkması turist sayısında ciddi düşüşlere neden olabilmektedir (Elliot ve Ryan, 1993; Kelly, 1993; Prideaux ve Dunn, 1995; Pizam ve Mansfeld, 1996:1; Dimanche ve Lepetic, 1999; Pelfrey, 1998; Tarlow, 2000; Levantis ve Gani, 2000; Cavlek, 2002). Ryan'a göre (1993) suç, destinasyonun emniyetli imajının kırılgan doğasına önemli bir darbe vurarak turizm talebini engelleyebilmektedir. Bu durum turizm sektörüne ciddi zararlar verebileceği gibi bölgede turizmin düşüşüne de sebep olabilmektedir. Dahası, potansiyel turistler, yüksek bir suç oranı ününe sahip bir destinasyonu ziyaret etmeme yönünde karar verebildikleri gibi; onların konaklama tesisi dışında etkinliklere katılmaları, başkalarına destinasyonu tavsiye etmeleri, aynı destinasyona tekrar gelmeleri de olası değildir (George, 2003:577; Pizam ve Mansfeld, 2006; Batra, 2008:92,93). Bu da bir turizm destinasyonun başarısında emniyet ve güvenliğin mutlak öncelikler arasında olduğunu göstermektedir

Güvenlik ve emniyet algısı, destinasyon hakkında karar-alma süreci boyunca belirleyici faktörlerin başında gelmektedir (Sönmez ve Graefe, 1998a, 1998b; Mawby, 2000; George, 2003; Rittichainuwat ve Chakraborty, 2009; Çetinsöz ve Ege, 2013). Karar-alma süreci, belirli eylemler tarafindan şekillenen ve farklı aşamalardan oluşan, bir dizi psikolojik (içsel) ve psikolojik olmayan (dışsal) değiş̧kenler tarafından etkilenmektedir (Sırakaya ve Woodside, 2005). İ̧sel unsurlar pozitif olsa bile dışsal etkenlerin algılanmasında önemli bir belirleyici olan emniyet ve güvenlik olgusu, algıyı ve motivasyonu etkileyerek karar-alma sürecinde merkezi bir rol oynamaktadır (Ferreira ve Harmse, 2000; Mawby, 2000; Amir ve diğ., 2015:124).

Kısacası, turistin karar-alma sürecinin en başından seyahatinin sonuna kadar güvenlik ve emniyet öncelikli bir konu olarak görünmektedir. Gerçekten de turistin olumsuz güvenlik algısı, öncelikle tatil planlarını değiştirmelerine, tatil esnasında yaşadığı olumsuz deneyimlerden kaynaklı güvenlik endişesi ya da tehdidi ise, tekrar bölgeyi ziyaret etmeme veya başkalarına tavsiye etmeme gibi davranışlara neden olabilecek bir dizi olumsuz sonuçlara neden olabilmektedir.

\section{Risk ve Algılanan Risk}

Son zamanlarda uluslararası seyahatle ilgili önemli bir endişe olarak kabul edilen "risk", uluslararası seyahatin değerlendirilmesinde önemli bir faktör olarak vurgulanmaktadır (Yavaş, 1987; Sönmez ve Graefe, 1998a, 1998b; Lepp ve Gibson, 2003; Reisinger ve Mavondo, 2005; Qi ve diğ., 2009). Kitlesel ve küresel turizmin artmasiyla birlikte emniyet ve güvenlik bağlamında "algılanan risk"in seyahat kararlarını etkileyen önemli bir faktör olduğu ortaya konmuştur (Surakaya ve diğ., 1997; Sönmez ve Graefe, 1998b). Özellikle 90'lardan sonra turizm güvenliğine ilişkin çalışmaların çoğu, turizmde riski tartışmakla birlikte, önemli bir kısmı ise gerçek riskten ziyade "algılanan risk" üzerine odaklanmıştır (Roehl ve Fesenmaier, 1992; Maser ve Weiermair, 1998; Sönmez ve Graefe, 1998a, 1998b).

Turistin karar-alma sürecinde önemli bir rol oynayan risk, tüketicinin davranışı üzerinde olası olumsuz sonuçlara yol açacak istenmeyen olayların olasılığı olarak tanımlanmıştır (Laws ve Prideaux, 2005). Diğer yandan algılanan risk mutlak risk ya da gerçek riskten oldukça farklı olduğu vurgulanmıştır (Haddock, 1993). Haddock (1993) riski üçe ayırarak incelemiştir; Mutlak/Kesin Risk (hiçbir güvenlik önleminin olmadığı) herhangi bir durumun doğasında var olan riskin en üst seviyesidir. Gerçek Risk; belirli bir zamandaki gerçekte olan risk miktarıdır (güvenlik tedbirleri alınmış mutlak risktir). Algılanan risk ise; bir bireyin belirli bir zamanda gerçek riskle ilgili öznel değerlendirmesidir. Reisinger ve Mavondo'ya (2005) göre algılanan risk, tehdit ve tehlikeye maruz kalınacağının bilişsel olasılığı olarak tanımlanıştır. Genelde, turistler seyahat kararlarını gerçeklerden ziyade algılar üzerine temellendirerek yaptıkları literatürde belirtilmektedir (Irvine ve Anderson, 2006). Turistler tehlikeli bir durumda, kendilerini riske istekli olmayacakları ve herhangi bir belirsizlikten kaçınma isteyecekleri için önleyici bir karar olarak algılarını kullanma eğilimdedirler (Roehl ve Fesenmaier, 1992). Seyahat karar-alma sürecinde belirgin bir isteksizlik ve kaçınmayı ortaya çıkaran bu algı, mutlak ya da gerçek riskten daha fazla etkin olabilmektedir. Yapılan çalışmalar turistlerin seyahat niyetlerinin ve destinasyon tercihinin algılanan riskten etkilendiğini göstermektedir (Sönmez ve Graefe, 1998b). Algılanan bir risk yanlış bir seyahat kararına dönüşeceğinden, turist böyle bir riskin yüksek olduğunu hissettiğinde rezervasyon iptali, yaptırmama, erteleme ya da destinasyondan kaçış yönünde tatil planlarını ve davranışlarını değiştirebilmektedir (Maser ve Weiermair, 1998; George, 2003: 577; Sasso, 2005; Pizam ve Mansfeld, 2006; Irvine ve Anderson, 2006). Kısacası araştırmalar, turistlerin belirli bir destinasyona seyahatini iptal etmesi ya da değiştirmesi gerçek risklerden ziyade algılanan risklerden kaynaklandığını (Mitchell ve Vasso, 1997; Irvine ve Anderson, 2006) ve gerçeklerden ziyade algılara göre seyahat kararlarını verdikleri görülmektedir.

Turistlerin risk algılarının, özellikle heyecan aramaya eğilimli kişilere özgü kişilik tipi, sosyal sınıf, eğitim, seyahat bilgi kaynakları, kültür/milliyet, yaş ya da yaşam evresi, kalış süresi, cinsiyet, motivasyon, seyahatin amacı ve geçmiş seyahat deneyimleri gibi sosyo-ekonomik faktörlerden etkilendiğini ve bu faktörlere göre 
değişiklik gösterdiği tespit edilmiştir (Roehl ve Fesenmaier, 1992; Sönmez ve Graefe, 1998a, 1998b; Pizam ve diğ., 2002; Lepp ve Gibson, 2003; Reisinger ve Mavondo, 2005; George, 2010:809). Gerçekte turistler her zaman riski eşit düzeyde algılamazlar. Risklerin bazısı çekiciyken bazıları iticidir (Pizam ve diğ., 2002; Lepp ve Gibson, 2003). Risk algısını etkileyen faktörlerin belirlenmesi, seyahat niyeti ile destinasyon imajı arasındaki ilişsinin daha iyi anlaşılmasına katkıda bulunur (Qi ve diğ, 2009:46).

Turistler bahsedilen riskleri, hiç ya da en az satın alabilecekleri tercihleri yapmak isterler. Zira riski satın almak turizmin amacına çok kez ters düşebilmektedir. Turistlerin en az tehlikeli olarak algılanan bir destinasyonu tercih etmeleri, çok daha büyük bir olasılık olarak görünmektedir. Olumsuz algılara yol açmayacak destinasyonun pozitif imajı, sürdürülebilir ziyaretçi talebini ve bir destinasyonun geleceğini çok derin etkileyebileceği bilinmektedir (Donaldson ve Ferreira 2009). Gerçekten de algılanan risk, destinasyon imajıyla doğrudan ilgilidir (Lepp ve Gibson, 2003).

\section{Milliyetlere/Ülkelere Göre Güvenlik Algı Düzeylerinin Farklılığı}

Turizm güvenliği konusunda yapılan çalışmalarda, turistlerin seyahat motivasyonu, tutum, algı, beklenti ve davranışlarının kültürel farklılıklar ya da milliyetlerinden etkilendiğini ve güvenlik algılarının farklı olduğu görülmüştür. Richardson ve Crompton'un (1988) ifade ettiği gibi, farklı milletlerden turistlerin aynı riski, farklı düzeylerde algılayabilmektedirler. Örneğin Seddighi ve diğ. (2001), uluslararası turizmle ilişkili olarak risk algısının milliyetlere göre farklılık gösterdiğini tespit etmişlerdir. 6 Batı Avrupa ülkesinden gelen turistlerin risk algı düzeylerinin birbirlerinden farklı olduklarını ortaya koymuşlardır.

Guam'1 ziyaret eden turistlerin tipik tatil faaliyetlerine odaklanarak güvenlik endişelerini araştıran Pinhey ve Iverson (1994:92) Guam'a gelen Japon ziyaretçilerin diğer ülkelerden gelen ziyaretçilere göre güvenlik konusunda daha hassas olduklarını ve boş zaman aktiviteleri esnasında daha genç ve daha zengin Japon turistlerin kendilerini daha az güvende hissettiklerini ortaya koymuşlardır (George, 2003:57; Batra, 2008:91).

Benzer şekilde George (2003), ziyaretçilerin geldikleri ülke ile karanlık çöktükten sonra Cape Town sokaklarında yürümekten korkma seviyesi arasında istatistiksel olarak anlamlı bir ilişki bulmuştur. İngiltere ve Almanya'dan gelen katılımcılar, karanlık çöktükten sonra Cape Town'un sokaklarında yürümeyi güvensiz veya emniyetsiz olarak gördüklerini belirtmiştir. Amerikalılar karanlık çöktükten sonra Cape Town sokaklarında yürümeyi makul derecede güvenli bulurken ve Cape Town'u güvenli olarak tavsiye etmeye eğilimli iken, Almanlar Cape Town'u sadece makul derecede ziyaret edilebilecek güvenli bir yer olarak tavsiye etmekte ve karanlık çöktükten sonraki güvenlik konusunda ise emin olmadıkları gözlemlenmiştir (George, 2003: 583).

Chang’ın (2011) Tayvan'da yapmış olduğu araştırmada, farklı kültür ve ülkelerden gelen turistlerin, konaklama, ulaşım, tıbbi destek ve yasal düzen konularında anlamlı istatistiksel farklılar bulunmuştur. Araştırmaya göre, Asya'dan gelen turistlerin ulaşım ve tıbbi destek konusunda Amerika, Avrupa ve Okyanusya bölgesinden gelen turistlere nazaran daha fazla risk algıladıkları; Okyanusya'dan gelen turistler konaklama faktörü açısından Asya ve Amerika bölgesinden gelen turistlere göre daha az risk algıladıkları; Okyanusya'dan gelen turistler yasal düzen faktörü açısından Asya ve Avrupa bölgesinden gelen turistlere göre daha fazla risk algıladıkları görülmüştür (Chang, 2011:35).

Barker ve Page (2002:277), Yeni Zelanda Aucland'daki Amerika Kupası 2000 müsabakasına giden uluslararası turistlerden Japonların, saldırı ve soygun konusuna, diğer ülkelerden gelen turistlerden daha fazla önem verdiklerini tespit etmişlerdir. Yapılan başak bir araştırmada ise Amerikalı turistlerin gündüz şehir turu yaparken kendilerini Hollandalı ve Güney Afrikalı turistlerden daha güvenli hissettiklerini tespit edilmiştir (George ve Booyens, 2014:461)

Batra (2008:97) tarafından yapılan bir çalışmada ise Amerikalı ve Afrikalı turistler gündüz vakti gezerken Bangkok'u “çok güvenli” bulurken; Asyalı ve Avrupalı turistler ise, "oldukça güvenli” bulmuşlardır. Afrikalı turistlerin saldırı ya da soyulma konusunda neredeyse hiç endişeli değilken; Avrupalı ve Amerikalı turistlerin biraz, Asyalı turistlerin ise orta düzeyde endişeli oldukları tespit edilmiştir. Aynı şeklide Sönmez (1998) Amerikalı turistlerin, diğer ülkelerden gelen turistlerle uluslararası seyahat ile ilgili risk algıları karşılaştırıldığında, daha yüksek risk algılama eğiliminde olduklarını vurgulamıştır. George ve Swart (2012:27), 2010 FIFA Dünya Kupası müsabakalarına gelen turistlerin suç-risk algılarını inceledikleri çalışmada, Avustralya ve İngiltere'den gelen turistlerin Asya'dan gelen turistlere göre geceleri daha güvenli hissettiklerini ortaya koymuşlardır.

Yukarıda bahsedilen çalışmaların sonucu, turistler arasındaki farklılıkların tespit edilerek, farklı ülkelerden gelen turistlerin memnuniyetini artırmak amacıyla farklı pazarlama stratejilerinin uygulanması gerekliliğini ortaya koymaktadır (Chang, 2011:26). Diğer yandan ülkelere göre risk algılamalarının farklılığının tespit edilmesi, farklı uyruktan olan turistlerin tatil memnuniyetini maksimize etmek bakımından da önemlidir. 


\section{Metodoloji}

Araştırmanın evreni 2012 yılında farklı ülkelerden Alanya'ya tatile gelen yabancı turistlerden oluşmaktadır. Araştırmanın örneklemini ise Alanya kent merkezine gelen yabancı turistlerden rastgele seçilen 500 yabancı kişiden oluşmuştur. Örneklem yöntemi olarak "Kolayda Örneklem Yöntemi” kullanılmıştır. Örneklem büyüklügünün hesaplanmasında kabul edilebilir hata payı 0.05 (\%5) olarak kabul edilmiş, \%95'lik güven seviyesine göre minimum örneklem büyüklüğü, örneklem belirleme çizelgesinden yararlanılarak 384 olarak hesaplanmıştır. Ancak anketlerin hatalar ya da eksik veri gibi nedenlerle yeterli sayıda geri dönmeyebileceği düşünülerek turistlere 550 anket uygulanmış; geri dönen anketlerden eksik/hatalı doldurulanlar çıkarıldıktan sonra 500 anket araştırma için kullanılmıştır.

Araştırmada literatür taraması ve alan araştırması yöntemi kullanılmıştır. Literatür taramasında ikincil kaynaklardan yararlanılırken, alan araştırmasında çalışmanın amacını ortaya koyacak nitelikte bir anket formu kullanılmıştır. Söz konusu anket formu, deneklerin demografik özelliklerini ve araştırma alanıyla ilgili güvenlik/risk algılarını belirlemeye yönelik sorulardan oluşmaktadır. Araştırma bölgesine çok farklı ülke/milletlerden turist gelmesi ve gelen turistlerin çok farklı dilleri konuşuyor olmasından dolayı anket formları İngilizce, Almanca ve Rusça dillerinde hazırlanmıştır. Anket, 2012'de sezonun en yoğun olduğu TemmuzAğustos aylarında kent merkezindeki turistlerin risk altında kalabilecekleri ve yoğun olarak zaman geçirdikleri bar, restoran, kafe, plaj ve otellerde uygulanmıştır. Ayrıca verilerin analizinde ülkelerin sınıflandırılmasında coğrafi bölümleme esas alınmıştır.

Anket uygulaması sonucu elde edilen veriler SPSS paket programında analiz edilmiştir. Verilerin işlenmesi konusunda yapılan analiz iki aşamadan oluşmaktadır. Birinci aşamada deneklerin tüm sorulara verdikleri cevapları frekans çizelgeleri ile gösterilerek, cevapların düzeylere göre dağılımı belirlenmiştir. İkinci aşamada ise gelinen ülke grupları ile taşıma araçlarında, gece ve gündüz yaya olarak dışarı çıktıklarında, plajlarda, eğlence mekânlarında, hırsızlık, kap-kaç, cinsel taciz, suç ve trafik durumunda güvenlik algılarını incelemek için ki-kare testi yapılmıştır. Gelinen ülke grupları ile cinsel taciz, hırsızlık, kap-kaç ve trafik kazasına maruz kalmaları durumundaki risk algıları arasında bir ilişkileri belirmek için ise ANOVA testi yapılmıştır. Ki-kare testinde boş hipotez yani $\mathrm{H}_{0}$ hipotezi sorulara verilen cevaplar arasında "ilişki yoktur/fark yoktur" $\left(\mathrm{H}_{0}\right.$ : değişkenler arasında ilişki yoktur) ve alternatif hipotez yani $\mathrm{H}_{\mathrm{A}}$ hipotezi ise sorulara verilen cevaplar arasında "ilişki vardır/en az biri farklıdır” ( $\mathrm{H}_{\mathrm{A}}$ : değişkenler arasında ilişki vardır) şeklinde oluşturulmuştur. Ki-kare ve ANOVA testi yardımıyla aşağıdaki hipotezler test edilmiştir.

$\mathbf{H}_{\mathbf{0}}$ : Turistlerin geldikleri ülke grupları ile toplu taşıma araçlarında, gece ve gündüz yaya olarak dışarı çıktıklarında, plajlarda ve eğlence mekânlarında güvenlik algıları arasında bir ilişki yoktur.

$\mathbf{H}_{\mathbf{A}}$ : Turistlerin geldikleri ülke grupları ile toplu taşıma araçlarında, gece ve gündüz yaya olarak dışarı çıktıklarında, plajlarda ve eğlence mekânlarında güvenlik algıları arasında bir ilişki vardır.

$\mathbf{H}_{\mathbf{0}}$ : Turistlerin geldikleri ülke grupları arasında turistlerin cinsel tacize, hırsızlığa, suça, kap-kaça ve trafik kazasına maruz kalmaları durumunda risk algıları bakımından bir fark yoktur.

$\mathbf{H}_{\mathbf{A}}$ : Turistlerin geldikleri ülke grupları arasında turistlerin cinsel tacize, hırsızlı̆̆a, suça, kap-kaça ve trafik kazasına maruz kalmaları durumunda risk algıları bakımından en az biri farklıdır.

\section{Araştırma Bulguları ve Değerlendirmesi}

\begin{tabular}{|c|c|c|c|c|c|c|c|c|c|c|c|c|c|}
\hline \multirow{2}{*}{\multicolumn{2}{|c|}{$\begin{array}{c}\text { Ülke Grupları } \\
\text { Demografik Değișkenler }\end{array}$}} & \multicolumn{2}{|c|}{$\begin{array}{c}\text { Batı } \\
\text { Avrupa } \\
\end{array}$} & \multicolumn{2}{|c|}{$\begin{array}{l}\text { Kuzey } \\
\text { Avrupa } \\
\end{array}$} & \multicolumn{2}{|c|}{$\begin{array}{c}\text { Orta } \\
\text { Avrupa } \\
\end{array}$} & \multicolumn{2}{|c|}{$\begin{array}{c}\text { Doğu } \\
\text { Avrupa } \\
\end{array}$} & \multicolumn{2}{|c|}{$\begin{array}{c}\text { Diğer } \\
\text { ülkeler }\end{array}$} & \multicolumn{2}{|c|}{ Toplam } \\
\hline & & f & $\%$ & f & $\%$ & $\mathbf{f}$ & $\%$ & f & $\%$ & f & $\%$ & $\mathbf{f}$ & $\%$ \\
\hline \multirow{2}{*}{ Cinsiyet } & Erkek & 49 & 24,7 & 79 & 39,9 & 20 & 10,1 & 42 & 21,2 & 8 & 4 & 198 & 39,6 \\
\hline & Kadın & 53 & 17,5 & 120 & 39,7 & 34 & 11,3 & 76 & 25,2 & 18 & 6,3 & 302 & 60,4 \\
\hline \multirow{5}{*}{ Yaş } & 20 yaş altı & 22 & 22,2 & 49 & 49,5 & 14 & 14,1 & 11 & 11,1 & 3 & 3,0 & 99 & 19,8 \\
\hline & 21-30 yaş & 45 & 23,0 & 84 & 42,9 & 18 & 9,2 & 35 & 17,9 & 14 & 7,1 & 196 & 39,2 \\
\hline & $31-40$ yaş & 13 & 18,1 & 22 & 30,6 & 5 & 6,9 & 27 & 37,5 & 5 & 6,9 & 72 & 14,4 \\
\hline & 41-50 yaş & 11 & 17,2 & 19 & 29,7 & 11 & 17,2 & 22 & 34,4 & 1 & 1,6 & 64 & 12,8 \\
\hline & 61 ve üstü & 11 & 15,9 & 25 & 36,2 & 6 & 8,7 & 23 & 33,3 & 4 & 5,8 & 69 & 13,8 \\
\hline \multirow{3}{*}{$\begin{array}{l}\text { Medeni } \\
\text { durum }\end{array}$} & Evli & 36 & 18,1 & 64 & 32,2 & 19 & 9,5 & 69 & 34,7 & 11 & 5,5 & 199 & 39,8 \\
\hline & Bekâr & 57 & 23,4 & 115 & 47,1 & 28 & 11,5 & 29 & 11,9 & 15 & 6,1 & 244 & 48,8 \\
\hline & Boşanmış & 9 & 15,8 & 20 & 35,1 & 7 & 12,3 & 20 & 35,1 & 1 & 1,8 & 57 & 11,4 \\
\hline \multirow{5}{*}{ Eğitim } & İlköğretim & 12 & 38,7 & 11 & 35,5 & 4 & 12,9 & 2 & 6,5 & 2 & 6,5 & 31 & 6,2 \\
\hline & Lise & 40 & 23,5 & 93 & 54,7 & 22 & 12,9 & 13 & 7,6 & 2 & 1,2 & 170 & 34,0 \\
\hline & Ön lisans & 19 & 18,6 & 36 & 35,3 & 14 & 13,7 & 31 & 30,4 & 2 & 2,0 & 102 & 20,4 \\
\hline & Lisans & 11 & 8,5 & 33 & 25,4 & 10 & 7,7 & 63 & 48,5 & 13 & 10,0 & 130 & 26,0 \\
\hline & Lisansüstü & 20 & 29,9 & 26 & 38,8 & 4 & 6,0 & 9 & 13,4 & 8 & 11,9 & 67 & 13,4 \\
\hline \multirow{4}{*}{$\begin{array}{l}\text { Kalıș } \\
\text { Süresi }\end{array}$} & $\begin{array}{ll}\text { Bir } & \text { haftaya } \\
\text { kadar } & \\
\end{array}$ & 41 & 18,0 & 107 & 46,9 & 28 & 12,3 & 37 & 16,2 & 15 & 6,6 & 228 & 45,6 \\
\hline & İki hafta & 45 & 21,8 & 65 & 31,6 & 26 & 12,6 & 62 & 30,1 & 8 & 3,9 & 206 & 41,2 \\
\hline & Üç hafta & 13 & 37,1 & 11 & 31,4 & --- & --- & 10 & 28,6 & 1 & 2,9 & 35 & 7,0 \\
\hline & Dört hafta ve + & 3 & 9,7 & 16 & 51,6 & --- & --- & 9 & 29,0 & 3 & 9,7 & 31 & 6,2 \\
\hline
\end{tabular}




\begin{tabular}{|c|c|c|c|c|c|c|c|c|c|c|c|c|c|}
\hline \multirow{5}{*}{$\begin{array}{c}\text { Kiminle } \\
\text { Tatile } \\
\text { Çıktığı }\end{array}$} & Yalnız & 4 & 12,5 & 11 & 34,4 & --- & --- & 12 & 37,5 & 5 & 15,6 & 32 & 6,4 \\
\hline & Kar1/Koca & 32 & 19,4 & 52 & 31,5 & 18 & 10,9 & 54 & 32,7 & 9 & 5,5 & 165 & 33,0 \\
\hline & Arkadaşlarla & 39 & 22,4 & 85 & 48,9 & 18 & 10,3 & 25 & 14,4 & 7 & 4,0 & 174 & 34,8 \\
\hline & Aile & 8 & 17,8 & 16 & 35,6 & 7 & 15,6 & 12 & 26,7 & 2 & 4,4 & 45 & 9,0 \\
\hline & Diğer & 19 & 22,6 & 35 & 41,7 & 11 & 13,1 & 15 & 17,9 & 4 & 4,8 & 84 & 16,8 \\
\hline
\end{tabular}

Tablo. 1 Demografik Değişkenler Tablosu

Araştırma kapsamında Tablo 1'e göre, Alanya'ya gelen turistlerin \%39.6'nın erkek ve \%60,4'ünü ise kadın olduğu tespit edilmiştir. Ülke gruplarına göre incelendiğinde ise Batı Avrupa ülkeleri dışından Alanya'ya gelen turistler cinsiyetleri bakından benzerlik gösterdiği görülmektedir. Batı Avrupa ülkelerinden erkeklerin (\%24.7) kadınlara (\%17.5) oranla daha fazla araştırma bölgesini tercih ettiği tespit edilmiştir. Araştırma bölgesine gelen turistlerin çoğunluğunun (\%59) 30 ve altı yaş grubundan oluştuğu Tablo 1'de görülmektedir. Ülke gruplarına göre araştırma bölgesine gelen turistlerin yaş dağılımı incelendiğinde, 30 ve altı yaş gruplarında Kuzey Avrupa'dan gelenlerin oranı (daha fazla iken 30 ve üstü yaş gruplarında) Doğru Avrupa'dan gelen turistlerin oranından daha fazla olduğu görülmektedir. Araştırma gölgesine gelen turistlerin \% 49'unun bekar ve \%40'1nın evli olduğu tespit edilmiştir. Tatil amaciyla araştırma bölgesine gelen evli turistlerin büyük çoğunluğunu Doğu Avrupalı turistler oluşturuyorken bekar turistlerin büyük çoğunluğunu ise Kuzey Avrupa ülkelerinden gelen turistlerden oluştuğu görülmektedir.

Araştırma bölgesine gelen turistlerin büyük bir çoğunluğunun lisans ve lisans-üstü eğitim (\%59.8) düzeyine sahip olduğu görülmekte olup lise ve altı eğitime sahip olanların oranı $\% 40.2$ düzeyinde olduğu tespit edilmiştir. Tablo 1 incelendiğinde, lisans-üstü eğitim düzeyine sahip olan ülkeler içerisinde ilk sırada Kuzey Avrupa ülkeleri (\%38.8), lisans eğitim düzeyinde Doğu Avrupa ülkeleri (\%48.5) ve lise düzeyinde ise Kuzey Avrupa ülkeleri (\%54.7) ilk sirada görülmektedir.

Araştırma bölgesine gelen yabancı turistlerin büyük bir çoğunluğu bir hafta ve daha kısa süreli tatil için Alanya'da bulunduğunu beyan etmiş olup iki hafta ve daha uzun süre araştırma bölgesinde kalanların oranı oldukça düşük düzeyde kalmıştır (\%13.2). Araştırma bölgesine gelen turistlerden iki hafta ve daha kısa süreli tatil için gelenlerin içerisinde ilk sırayı Kuzey Avrupa ülkeleri, üç hafta için gelenlerin içerisinde Batı Avrupa ülkeleri ve dört hafta ve daha fazla süre Alanya'da bulunanlar içerisinde ise yine Kuzey Avrupa ülkelerinden gelenler ilk sırada yer almaktadırlar.

Araştırma bölgesine gelen turistlerin büyük bir çoğunluğu eşleriyle (\%33) veya arkadaşlarıyla (\%34.8) tatile gelmekteyken yalnız (\%6.4) veya ailesi (\%9) ile birlikte tatile gelenlerin oranı oldukça düşük düzeyde kaldığı gözlemlenmiştir. Doğu Avrupa ülkelerinden gelenlerin \%37.5'i Alanya'ya yalnız gelmeyi tercih ederken Kuzey Avrupa ülkelerinden gelenlerin ise arkadaşları ile birlikte gelmeyi tercih ettikleri tespit edilmiştir.

Tablo 2'ye göre ise, Alanya kent merkezine tatile gelen yabancı turistlerin \%90,6'sı Alanya kent merkezini güvenli bulduklarını ifade ederken güvensiz olduğunu belirtenlerin oranı ise $\% 9.4$ olarak tespit edilmiştir. Alanya kent merkezini güvenli bulanların ülke gruplarına göre dağılımı incelendiğinde; ilk sırada Kuzey Avrupa ülkelerinden gelenler yer alırken (\%40,0); bunu sırasıyla Doğu Avrupa (\%23) ve Batı Avrupa ülkelerinden $(\% 20,8)$ gelenler takip etmektedir. Araştırma kapsamında Alanya'nın güvenli bir kent olup olmaması bakımından kendi yaşadığı kent/ülke ile mukayese etmesi istenen turistlerin \%55.8'i kendi kentlerinin daha güvenli olduğunu belirtirken, Alanya'yı kendi kentlerinden daha güvenli bulanların oranı ise \% 14.8 ve her iki kent arasında güvende hissetme bakımından fark yok diyenlerin oranı ise \%29.4 düzeyinde olduğu görülmektedir. Kuzey Avrupa ülkelerinden gelen turistler kendi yaşadıkları kentin Alanya'dan daha güvenli (\%48) bir kent olduğunu beyan ederken Doğu Avrupa ülkelerinden gelenler ise Alanya'nın daha güvenli bir kent olduğunu ifade etmişlerdir $(\% 47,3)$.

Alanya’ya gelmeden önce Alanya’yı güvenli bir kent bulmayanların oranın \%22.4 gibi düşük bir seviyede kalması, Alanya'nın destinasyon imajının genel olarak güvenli bir kent olarak algılandığını göstermektedir. Dolayısıyla Alanya'nın güvenli bulunma oranın yükselmesi, Alanya'ya gelen turistlerin daha sonradan güvenli olduğu yönünde bir alg1 değişiminin (Alanya'ya gelmeden önce Alanya hakkında güvenlik algısı olumsuz olanlardan \%34.6'sının olumlu olarak değişmesi) katkısı da göz önüne alındığında güvenli kent imajı pekişmektedir. Diğer bir ifade ile Alanya'ya gelmeden Alanya'yı güvenli bulup; geldikten sonra olumsuz olduğu yönde değişimin \%5.8 (29 kişi) gibi oldukça az bir oranda kalması, gerek verilen güvenlik hizmetlerine gerekse destinasyon imajına gerekse de risk algısının düşüklügüne bağlanabilir. İnsanların elbette kendilerini yabancısı oldukları bir ülkeye göre kendi ülkelerinde güvende hissetmeleri doğal bir durum olmakla birlikte, Alanya'yı kendi ülkesinden daha güvenli bulanlar ile kendi ülkesiyle fark yok diyenlerin toplam oranının \% 44.2 olması, Alanya’nın güvenli bir kent olduğunu gösteren diğer bir veridir. Turistlerin Alanya’yı kendi kentlerinden daha güvenli bulma oran1, \%14,8'dir. Tablo 2'deki veriler değerlendirildiğinde, Kuzey Avrupa ülkelerinden gelen turistlerin kendi ülkelerine göre Alanya'da kendilerini daha az (\%6.5) güvende hissetmekteyken, Doğu Avrupa ülkelerinden gelen turistler kendi ülkeleri ile karşılaştırdıklarında Alanya'da kendilerini daha güvende (\%29.7) hissettikleri ifade etmişlerdir. 
Bir kente verilen güvenlik hizmetlerinin kalitesinin yüksekliği o kentin güvenlik algısı üzerinde olumlu etki yapacağı kesindir. Araştırma kapsamında Alanya'ya gelen turistlerden Türk güvenlik görevlilerine güven düzeyi ve alınan güvenlik hizmetinin kalitesini değerlendirmesi istendiğinde, Türk güvenlik görevlilerine güvenenlerin oranı \%36.7 ve güvenmeyenlerin oranının ise \%5.6 düzeyinde olduğu tespit edilmiştir. Alanya'daki güvenlik görevlilerinin hizmetlerinden memnuniyet düzeylerini değerlendirilmesi istendiğinde ise \%13.8'i mükemmel olarak değerlendirirken, $\% 40.8$ ' $\mathrm{i}$ iyi, $\% 21^{\prime} \mathrm{i}$ ise orta olarak değerlendirmekte ve $\% 21.8$ ' $\mathrm{i}$ ise fikirlerinin olmadığını beyan etmişlerdir. Alınan güvenlik hizmetinin kalitesinin mükemmel olduğunu belirten 69 kişi içerisinde Doğu Avrupa ülkelerinden gelenler (\%40.6) ve iyi bulan 204 kişi içerisinde \%42,0 ile Kuzey Avrupa ülkelerinden gelenler ilk sırada yer almaktadırlar. Araştırma sonucu dikkate alındığında Alanya kent merkezine gelen turistlerin yaklaşık 3/4’ü güvenlik hizmetlerini kötü bulmamaktadır. Bu durum, güvenlik hizmet kalitesinin iyi olmasının aynı zamanda Alanya'yı güvenli bulmasında da etkin bir faktör olduğu söylenebilir. Diğer yandan farklı bir ülkede tatil yapan bir turistin güvenlik gibi hassas bir konuda, münferit bir olay yaşamadıkça bulunduğu ülkenin güvenlik gücüne ve hizmetlerine karşı olumsuz bir tutum takınması da pek olası değildir.

\begin{tabular}{|c|c|c|c|c|c|c|c|c|c|c|c|c|c|}
\hline \multirow{2}{*}{\multicolumn{2}{|c|}{$\begin{array}{c}\text { Ülke Grupları } \\
\text { Demografik değişkenler } \\
\end{array}$}} & \multicolumn{2}{|c|}{$\begin{array}{c}\text { Batı } \\
\text { Avrupa } \\
\end{array}$} & \multicolumn{2}{|c|}{$\begin{array}{l}\text { Kuzey } \\
\text { Avrupa } \\
\end{array}$} & \multicolumn{2}{|c|}{$\begin{array}{c}\text { Orta } \\
\text { Avrupa } \\
\end{array}$} & \multicolumn{2}{|c|}{$\begin{array}{c}\text { Doğu } \\
\text { Avrupa } \\
\end{array}$} & \multicolumn{2}{|c|}{$\begin{array}{c}\text { Diğer } \\
\text { ülkeler }\end{array}$} & \multicolumn{2}{|c|}{ Toplam } \\
\hline & & f & $\%$ & f & $\%$ & $\mathbf{f}$ & $\%$ & f & $\%$ & f & $\%$ & f & $\%$ \\
\hline \multirow{2}{*}{$\begin{array}{l}\text { Alanya'da kendinizi } \\
\text { güvende hissediyor } \\
\text { musunuz? }\end{array}$} & Evet & 94 & 20.8 & 181 & 40,0 & 49 & 10,8 & 104 & 23,0 & 25 & 5,5 & 453 & 90,6 \\
\hline & Hayır & 8 & 17,0 & 18 & 38,3 & 5 & 10,6 & 14 & 29,8 & 2 & 4,3 & 47 & 9,4 \\
\hline \multirow{3}{*}{$\begin{array}{lr}\text { Hangi } & \text { ülkede } \\
\text { /şehirde } & \text { kendinizi } \\
\text { daha } & \text { güvende } \\
\text { hissediyorsunuz? }\end{array}$} & Kendi ülkemde & 64 & 22,9 & 134 & 48,0 & 25 & 9,0 & 43 & 15,4 & 13 & 4,7 & 279 & 55,8 \\
\hline & Alanya'da & 14 & 18,9 & 13 & 17,6 & 5 & 6,8 & 35 & 47,3 & 7 & 9,5 & 74 & 14,8 \\
\hline & Fark yok & 24 & 16,3 & 52 & 35,4 & 24 & 16,3 & 40 & 27,2 & 7 & 4,8 & 147 & 29,4 \\
\hline \multirow{2}{*}{$\begin{array}{lr}\text { Alanya'ya } & \text { gelmeden } \\
\text { önce } & \text { Alanya } \\
\text { hakkında güvenlik } \\
\text { algınız nasıldı? }\end{array}$} & $\begin{array}{l}\text { Alanya } \\
\text { güvenlidir }\end{array}$ & 83 & 21,4 & 148 & 38,1 & 46 & 11,9 & 93 & 24,0 & 18 & 4,6 & 388 & 77,6 \\
\hline & $\begin{array}{l}\text { Alanya güvenli } \\
\text { değildir }\end{array}$ & 19 & 17,0 & 51 & 45,5 & 8 & 7,1 & 25 & 22,3 & 9 & 8,0 & 112 & 22,4 \\
\hline \multirow{3}{*}{$\begin{array}{l}\text { Alanya'ya geldikten } \\
\text { sonra Alanya ile } \\
\text { ilgili güvenlik } \\
\text { algınızda nasıl bir } \\
\text { değişme oldu? }\end{array}$} & $\begin{array}{l}\text { Olumlu olarak } \\
\text { değişti }\end{array}$ & 26 & 15,0 & 68 & 39,3 & 19 & 11,0 & 49 & 28,3 & 11 & 6,4 & 173 & 34,6 \\
\hline & $\begin{array}{l}\text { Olumsuz olarak } \\
\text { değişti }\end{array}$ & 6 & 20,7 & 9 & 31,0 & 1 & 3,4 & 12 & 41,4 & 1 & 3,4 & 29 & 5,8 \\
\hline & Değişmedi & 70 & 23,5 & 122 & 40,9 & 34 & 11,4 & 57 & 19,1 & 15 & 5,0 & 298 & 59,6 \\
\hline \multirow{2}{*}{$\begin{array}{l}\text { Alanya'nın güvenli } \\
\text { bir kent olduğunu } \\
\text { tavsiye eder misiniz? }\end{array}$} & Tavsiye ederim & 92 & 20,5 & 174 & 38,8 & 50 & 11,1 & 110 & 24,5 & 23 & 5,1 & 449 & 89,8 \\
\hline & Tavsiye etmem & 10 & 19,6 & 25 & 49,0 & 4 & 7,8 & 8 & 15,7 & 4 & 7,8 & 51 & 10,2 \\
\hline \multirow{4}{*}{$\begin{array}{l}\text { Türk güvenlik } \\
\text { görevlilerine } \\
\text { güveniyor musunuz? }\end{array}$} & Evet & 32 & 17,0 & 62 & 33,0 & 24 & 12,8 & 55 & 29,3 & 15 & 8,0 & 188 & 37,6 \\
\hline & Kismen & 27 & 20,0 & 60 & 44,4 & 9 & 6,7 & 32 & 23,7 & 7 & 5,2 & 135 & 27,0 \\
\hline & Hayır & 8 & 28,6 & 10 & 35,7 & 2 & 7,1 & 7 & 25,0 & 1 & 3,6 & 28 & 5,6 \\
\hline & Fikrim yok & 35 & 23,5 & 67 & 45,0 & 19 & 12,8 & 24 & 16,1 & 4 & 2,7 & 149 & 29,8 \\
\hline \multirow{6}{*}{$\begin{array}{l}\text { Alanya'daki } \\
\text { güvenlik } \\
\text { görevlilerinin } \\
\text { hizmetlerinden } \\
\text { memnuniyet } \\
\text { dereceniz nedir? }\end{array}$} & Mükemmel & 7 & 10,1 & 21 & 30,4 & 5 & 7,2 & 28 & 40,6 & 8 & 11,6 & 69 & 13,8 \\
\hline & İyi & 42 & 21,0 & 86 & 42,0 & 22 & 11,0 & 43 & 21,0 & 11 & 5,4 & 204 & 41,0 \\
\hline & Orta & 33 & 31,0 & 40 & 38,0 & 14 & 13,0 & 12 & 11,0 & 6 & 5,7 & 105 & 21,0 \\
\hline & Kötü & 1 & 12,5 & 3 & 37,5 & --- & --- & 4 & 50,0 & --- & --- & 8 & 1,6 \\
\hline & Çok kötü & 1 & 20,0 & 2 & 40,0 & --- & --- & 2 & 40,0 & --- & --- & 5 & 1,0 \\
\hline & Fikrim yok & 18 & 16,5 & 47 & 43,1 & 13 & 11,9 & 29 & 26,6 & 2 & 1,8 & 109 & 21,8 \\
\hline
\end{tabular}

Tablo. 2 Algı Değişkenleri Tablosu

\section{Hipotezlerin Test Edilmesi}

Araştırma bölgesine gelen turistlerin kendilerini en fazla güvende hissettikleri durumunun "gündüz yaya olarak dişarı çıkma" durumu olup bu oran \%80.0 olarak tespit edilmiş olup en düşük güvende hissettikleri durumun ise cinsel taciz durumu olduğu saptanmıştır (\%32.8). Araştırma bölgesine gelen turistlerin geldikleri ülke grupları ile toplu taşıma araçlarında, gece ve gündüz yaya olarak dışarı çıktıklarında, plajlarda ve eğlence mekanlarında, güvenlik algıları arasında bir ilişkinin varlığını araştırmak amacıyla ki-kare testi yapıılmıştır. "Toplu Taşıma Araçlarında", "Gece Yaya Olarak Dışarı Çıktığınızda" ve "Gündüz Yaya Olarak Dışarı Çıktığınızda" durumlarında gelinen ülke grubu ile güvenlik algıları arasındaki ilişkiyi belirlemeye yönelik yapılan ki kare testi sonucunda elde edilen ki kare değerleri sırasıyla 0.000, 0.028 ve 0,000 olarak hesaplanmıştır. Buna göre $\mathrm{P}<0,05$ olduğundan \%5 anlamlılık düzeyinde HA hipotezi kabul edilmiştir.

Tablo 3'e göre araştırma bölgesine gelen yabancı turistlerin kendilerini en fazla güvende hissettikleri durumunun "gündüz yaya olarak dışarı çıkma" durumu olup bu oran \%80.0 olarak tespit edilmiştir. Alanya'ya gelen yabancı turistlerin \%50.4'ü toplu taşıma araçlarında kendilerini güvende hissettiklerini ifade ederken benzer sonuçlar gece yaya olarak dişarı çıktıklarında (\%48.6) da gözlemlenmiştir. Araştırma bölgesine gelen yabancı turistlerin plajlarda ve eğlence mekanlarında da kendilerini güvende hissettiklerini görülmekte olup bu oranların sırasıyla \%45.8 ve \%42'dir. Toplu taşıma araçlarında kendilerini güvende hissettiklerini belirten 252 kişi içerisinde Kuzey Avrupa ülkelerinden gelenler (\%34,5) ilk sırada yer alırken bunu sırasıyla Doğu Avrupa ülkelerinden gelenler $(\% 25,8)$ ve Batı Avrupa ülkelerinden $(\% 17,1)$ gelenler takip etmektedir. Tablo 3 
incelendiğinde, gece ve gündüz yaya olarak dışarı çıkma durumunda, plajda ve eğlence mekanlarında kendini güvende hissetme durumlarında da ülke gruplarına göre benzer bir dağılım söz konusu olduğu görülmektedir.

$\boldsymbol{H}_{\boldsymbol{A}}$ Turistlerin geldikleri ülke grupları ile toplu taşıma araçlarında, gece ve gündüz yaya olarak dişarı çıktıklarında, plajlarda ve eğlence mekânlarında güvenlik algıları arasında bir iliş̧ki vardır.

\begin{tabular}{|c|c|c|c|c|c|c|c|c|c|c|c|c|c|c|c|c|}
\hline \multirow{2}{*}{\multicolumn{2}{|c|}{$\begin{array}{l}\text { Ülke Grupları } \\
\text { Değişkenler }\end{array}$}} & \multicolumn{2}{|c|}{$\begin{array}{c}\text { Batı } \\
\text { Avrupa }\end{array}$} & \multicolumn{2}{|c|}{$\begin{array}{c}\text { Kuzey } \\
\text { Avrupa }\end{array}$} & \multicolumn{2}{|c|}{$\begin{array}{c}\text { Orta } \\
\text { Avrupa }\end{array}$} & \multicolumn{2}{|c|}{$\begin{array}{c}\text { Doğu } \\
\text { Avrupa }\end{array}$} & \multicolumn{2}{|c|}{$\begin{array}{l}\text { Diğer } \\
\text { ülkeler }\end{array}$} & \multicolumn{2}{|c|}{ Toplam } & \multirow[b]{2}{*}{ क } & \multirow{2}{*}{ 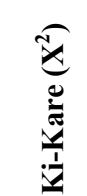 } & \multirow{2}{*}{$\mathbf{P}$} \\
\hline & & $\mathbf{f}$ & $\%$ & f & $\%$ & f & $\%$ & f & $\%$ & $\mathbf{f}$ & $\%$ & f & $\%$ & & & \\
\hline \multirow{3}{*}{$\begin{array}{l}\text { Toplu } \\
\text { taşıma } \\
\text { araçlarında }\end{array}$} & Evet & 43 & 17,1 & 88 & 34,9 & 35 & 13,9 & 65 & 25,8 & 21 & 8,3 & 252 & 50,4 & \multirow[t]{3}{*}{8} & \multirow[t]{3}{*}{28,544} & \multirow[t]{3}{*}{$0,000^{*}$} \\
\hline & Kismen & 45 & 24,3 & 91 & 49,2 & 10 & 5,4 & 36 & 19,5 & 3 & 1,6 & 185 & 37,0 & & & \\
\hline & Hayır & 14 & 22,2 & 20 & 31,7 & 9 & 14,3 & 17 & 27,0 & 3 & 4,8 & 63 & 12,6 & & & \\
\hline \multirow{3}{*}{$\begin{array}{l}\text { Gece yaya } \\
\text { olarak dışarı } \\
\text { çıktığınızda }\end{array}$} & Evet & 50 & 20,6 & 87 & 35,8 & 39 & 16,0 & 51 & 21,0 & 16 & 6,6 & 243 & 48,6 & \multirow[t]{3}{*}{8} & \multirow[t]{3}{*}{17,226} & \multirow[t]{3}{*}{$0,028^{*}$} \\
\hline & Kismen & 37 & 20,8 & 75 & 42,1 & 10 & 5,6 & 48 & 27,0 & 8 & 4,5 & 178 & 35,6 & & & \\
\hline & Hayır & 15 & 19,0 & 37 & 46,8 & 5 & 6,3 & 19 & 24,1 & 3 & 3,8 & 79 & 15,8 & & & \\
\hline \multirow{3}{*}{$\begin{array}{l}\text { Gündüz } \\
\text { yaya olarak } \\
\text { dışarı } \\
\text { çıktığınızda }\end{array}$} & Evet & 84 & 21,0 & 158 & 39,5 & 50 & 12,5 & 83 & 20,8 & 25 & 6,3 & 400 & 80,0 & \multirow[t]{3}{*}{8} & \multirow[t]{3}{*}{29,317} & \multirow[t]{3}{*}{$0,000^{*}$} \\
\hline & Kismen & 11 & 18,0 & 31 & 50,8 & 3 & 4,9 & 14 & 23,0 & 2 & 3,3 & 61 & 12,2 & & & \\
\hline & Hayır & 7 & 17,9 & 10 & 25,6 & 1 & 2,6 & 21 & 53,8 & --- & --- & 39 & 7,8 & & & \\
\hline \multirow{3}{*}{ Plajlarda } & $\overline{\text { Evet }}$ & 42 & $\overline{18,3}$ & 81 & 35,4 & 27 & 11,8 & $\overline{61}$ & 26,6 & 18 & $\overline{7,6}$ & 229 & 45,8 & \multirow[t]{3}{*}{8} & \multirow[t]{3}{*}{13,731} & \multirow[t]{3}{*}{0,089} \\
\hline & Kismen & 33 & 23,2 & 65 & 45,8 & 16 & 11,3 & 23 & 16,2 & 5 & 3,5 & 142 & 28,4 & & & \\
\hline & Hayır & 27 & 20,9 & 53 & 41,1 & 11 & 8,5 & 34 & 26,4 & 4 & 3,1 & 129 & 25,8 & & & \\
\hline \multirow{3}{*}{$\begin{array}{l}\text { Eğlence } \\
\text { yerlerinde }\end{array}$} & Evet & 46 & 21,9 & 83 & 39,5 & 23 & 11,0 & 42 & 20,0 & 16 & 7,6 & 210 & 42,0 & & \multirow[t]{3}{*}{6,938} & \multirow[t]{3}{*}{0,543} \\
\hline & Kismen & 30 & 18,1 & 67 & $\begin{array}{l}40,4 \\
\end{array}$ & 20 & 12,0 & 42 & 25,3 & 7 & 4,2 & 166 & 33,2 & & & \\
\hline & Hayır & 26 & 21,0 & 49 & 39,5 & 11 & 8,9 & 34 & 27,4 & 4 & 3,2 & 124 & 24,8 & & & \\
\hline
\end{tabular}

Tablo. 3 Alanya'da Turistlerin Ülke Grupları İle Çeşitli Ortamlarda Kendilerini Güvenli Hissetme Durumlarının Dă̆glımı

Tablo 4'e göre, araştırma bölgesine gelen turistlerin hırsızlık olayı ile karşılaşma durumlarının dağılımında $\% 30,8$ 'i az riskli \%27'si orta riskli olarak algılarken risk yok diyenlerin oranı \%17.4 olarak gerçekleşmiştir. Benzer bir durum kapkaç olayında karşılaşmaları durumundaki risk algılarının dağılımında da görülmektedir. Nitekim araştırma bölgesine gelen turistlerin kap-kaç olayının gerçekleşme risk algılarının dağılımında ilk sırada orta riskli bulanlar (\%34) oluştururken bunu az riskli bulanlar \%26,4 ile takip ettiği tespit edilmiştir. Cinsel tacize uğrama riskinin dağılımı incelendiğinde ise turistlerin \%11,4'ü yüksek riskli, \%22,2'si orta riskli, \%29,4 düşük riskli bulduklarını ifade ederken, cinsel tacize uğrama riskinin olmadığını belirtenlerin oranı $\% 22,2$ düzeyinde olduğu tespit edilmiştir. Araştırma kapsamında görüşme yapılan yabancı turistlerin yaklaşık $\% 55^{\prime} \mathrm{i}$ kriminal suçlarla (saldırı, yaralama ya da öldürmeye teşebbüs) karşılaşma riskinin olduğunu ifade ederken \% 26'si böyle bir risk algılarının olmadığını beyan etmişlerdir. Turistlerin en yüksek risk algıladıkları durumun ise trafik kazası durumu olduğu tespit edilmiştir (\%80). Trafik kazası durumuyla karşılaşma riskini yüksek risk algısı olarak algılayanların oranı \%29.1; orta riskli algılayanların oranı $\% 28.9$ ve az riskli olarak algılayanların oranı \%21.6 iken risksiz olduğunu ifade edenlerin oranı ise oldukça düşük düzeyde kaldığı tespit edilmiştir $(\% 8,4)$. Alanya'ya gelen yabancı turistlerin yaklaşık $\% 35$ 'i terör olayı ile karşılaşma riskinin olmadığını ifade eder iken yüksek risk olarak algıladıklarını belirtenlerin oranı ise \%4 düzeyinde kalmıştır.

ANOVA tablosuna göre turistlerin geldikleri ülke grupları algılanan hırsızlık, kap-kaç, cinsel taciz, kriminal suçlar ve terör risklerinde farklılığa neden olmaktadır. Diğer bir ifade ile farklı durumlarda ülke grupları farklı seviyelerde risk algılamaktadır. "Hırsızlık", "kap-kaç", "cinsel taciz", "kriminal suçlar" ve "terör" riskleri için $\mathrm{H}_{\mathrm{A}}$ hipotezi kabul edilirken "trafik" için ise istatistiksel olarak anlamlı bir fark bulunamamıştır. Söz konusu bu farklılı̆ıın hangi ülke gruplarının bu farklılığa neden olduğunu tespit etmek amacıyla Post-Hoc testlerden Benforini testi uygulanmıştır.

Benforini testi sonucunda; "Hırsızlık" riski algısı konusunda Doğu Avrupa ülkelerinden gelen turistlerin Kuzey Avrupa ülkelerinden gelen turistlerden ayrıştığı görülmektedir. Ülke gruplarının risk algılarının ortalamaları incelendiğinde Doğu Avrupa'dan gelen turistlerin daha yüksek "hırsızlık" riski algıladıkları görülmektedir $(\mathrm{p}<0,05)$. Diğer ülke grupları istatistiksel olarak anlamlı bir farklılığa yol açmamaktadırlar.

"Kap-kaç" güvenlik riski algısı konusunda Post-Hoc testleri bir farklılık yakalamakta başarısız olmuşlardır. Bu nedenle hangi ülke grubunun farklılaştı̆̆ını tespit etmek için ülke gruplarına ikişerli olarak Bağımsız Örneklemler t-testi uygulanmıştır. Bağımsız Örneklemler t-testi sonuçlarına göre Orta Avrupa, Batı Avrupa ve Kuzey Avrupa ülkelerinden gelen turistlerden farklılaşmaktadır ve daha yüksek "kap-kaç" riski algılamaktadırlar $(\mathrm{p}<0,05)$. Diğer ülke gruplarından gelen turistler, Batı Avrupa'dan ve Kuzey Avrupa'dan gelen turistlerden daha yüksek "kap-kaç" riski algılamaktadır. 
“Cinsel taciz" risk algısı konusunda yine Doğu Avrupa ülkelerinden gelen turistlerin Kuzey Avrupa ülkelerinden gelen turistlerden ayrıştığı görülmektedir. Ülke gruplarının risk algılarının ortalamaları incelendiğinde Doğu Avrupa'dan gelen turistlerin daha yüksek "cinsel taciz" riski algıladıkları görülmektedir. Diğer ülke grupları istatistiksel olarak anlamlı bir farklılığa yol açmamaktadırlar.

"Kriminal suçlar" risk algısı konusunda Orta Avrupa ülkeleri grubundan gelen turistler, Kuzey Avrupa, Orta Avrupa ve Batı Avrupa ülkelerinden farklılaşmaktadır, Orta Avrupa ülkelerinden gelen turistler risk algısı değişkeninin aritmetik ortalamaları baz alındığında Kuzey Avrupa, Orta Avrupa ve Batı Avrupa ülkelerinden daha yüksek "kriminal suçlar" riski algılamaktadır.

“Terör” güvenlik riski algısı konusunda kriminal suçlar değişkenine oldukça benzer şekilde Orta Avrupa ülkeleri grubundan gelen turistler, Kuzey Avrupa, Orta Avrupa ve Batı Avrupa ülkelerinden farklılaşmaktadır. Orta Avrupa ülkelerinden gelen turistler risk algısı değişkeninin aritmetik ortalamaları baz alındığında Kuzey Avrupa, Orta Avrupa ve Batı Avrupa ülkelerinden daha yüksek “terör” riski algıladıkları tespit edilmiştir.

$\boldsymbol{H}_{A}$. Turistlerin geldikleri ülke grupları arasında cinsel tacize, hırsızlı̆̆a, suça, kap-kaça ve trafik kazasına maruz kalmaları durumunda risk algıları bakımından en az biri farklıdır.

\begin{tabular}{|c|c|c|c|c|c|c|c|c|c|c|c|c|c|c|c|c|}
\hline \multirow{2}{*}{\multicolumn{2}{|c|}{$\begin{array}{l}\text { Ülke Grupları } \\
\text { Değişkenler }\end{array}$}} & \multicolumn{2}{|c|}{$\begin{array}{c}\text { Batı } \\
\text { Avrupa }\end{array}$} & \multicolumn{2}{|c|}{$\begin{array}{c}\text { Kuzey } \\
\text { Avrupa }\end{array}$} & \multicolumn{2}{|c|}{$\begin{array}{c}\text { Orta } \\
\text { Avrupa }\end{array}$} & \multicolumn{2}{|c|}{$\begin{array}{c}\text { Doğu } \\
\text { Avrupa }\end{array}$} & \multicolumn{2}{|c|}{$\begin{array}{c}\text { Diğer } \\
\text { ülkeler }\end{array}$} & \multicolumn{2}{|c|}{ Toplam } & \multicolumn{3}{|c|}{$\begin{array}{c}\text { ANOVA Test } \\
\text { Değerleri }\end{array}$} \\
\hline & & $\mathbf{f}$ & $\%$ & $\mathbf{f}$ & $\%$ & f & $\%$ & f & $\%$ & $\mathbf{f}$ & $\%$ & f & $\%$ & SD & $\mathbf{F}$ & Sig \\
\hline \multirow{5}{*}{ Hirsızlık } & En fazla riskli & 5 & 14,3 & 20 & 57,1 & -- & - & 7 & 20,0 & 3 & 8,6 & 35 & 7,0 & \multirow{5}{*}{4} & \multirow{5}{*}{3,828} & \multirow{5}{*}{$0,004 *$} \\
\hline & Orta riskli & 26 & 19,3 & 65 & 48,1 & 21 & 15,6 & 17 & 12,6 & 6 & 4,4 & 135 & 27,0 & & & \\
\hline & Az riskli & 40 & 26,0 & 50 & 32,5 & 16 & 10,4 & 47 & 30,5 & 1 & 0,6 & 154 & 30,8 & & & \\
\hline & Risk yok & 8 & 9,2 & 26 & 29,9 & 16 & 18,4 & 27 & 31,0 & 10 & 11,5 & 87 & 17,4 & & & \\
\hline & Fikrim yok & 23 & 25,8 & 38 & 42,7 & 1 & 1,1 & 20 & 22,5 & 7 & 7,9 & 89 & 17,8 & & & \\
\hline \multirow{5}{*}{ Kap-kaç } & En fazla riskli & 13 & 20,6 & 36 & 57,1 & 1 & 1,6 & 12 & 19,0 & 1 & 1,6 & 63 & 12,6 & \multirow{5}{*}{4} & \multirow{5}{*}{2,944} & \multirow{5}{*}{$0,020^{*}$} \\
\hline & Orta riskli & 41 & 24,1 & 63 & 37,1 & 18 & 10,6 & 38 & 22,4 & 10 & 5,9 & 170 & 34,0 & & & \\
\hline & Az riskli & 26 & 19,7 & 45 & 34,1 & 18 & 13,6 & 38 & 28,8 & 5 & 3,8 & 132 & 26,4 & & & \\
\hline & Risk yok & 13 & 15,9 & 27 & 32,9 & 15 & 18,3 & 18 & 22,0 & 9 & 11,0 & 82 & 16,4 & & & \\
\hline & Fikrim yok & 9 & 17,0 & 28 & 52,8 & 2 & 3,8 & 12 & 22,6 & 2 & 3,8 & 53 & 10,6 & & & \\
\hline \multirow{5}{*}{$\begin{array}{l}\text { Cinsel } \\
\text { Taciz, } \\
\text { (fiili- sözlü) }\end{array}$} & En fazla riskli & 9 & 15,8 & 35 & 61,4 & 1 & 1,8 & 9 & 15,8 & 3 & 5,3 & 57 & 11,4 & \multirow{5}{*}{4} & \multirow{5}{*}{5,119} & \multirow{5}{*}{$0,000^{*}$} \\
\hline & Orta riskli & 27 & 24,3 & 42 & 37,8 & 9 & 8,1 & 28 & 25,2 & 5 & 4,5 & 111 & 22,2 & & & \\
\hline & Az riskli & 28 & 19,0 & 59 & 40,1 & 17 & 11,6 & 40 & 27,2 & 3 & 2,0 & 147 & 29,4 & & & \\
\hline & Risk yok & 22 & 19,8 & 31 & 27,9 & 23 & 20,7 & 25 & 22,5 & 10 & 9,0 & 111 & 22,2 & & & \\
\hline & Fikrim yok & 16 & 21,6 & 32 & 43,2 & 4 & 5,4 & 16 & 21,6 & 6 & 8,1 & 74 & 14,8 & & & \\
\hline \multirow{5}{*}{$\begin{array}{l}\text { Kriminal } \\
\text { suçlar, } \\
\text { (öldürmeye } \\
\text { teşebbüs, } \\
\text { yaralama }\end{array}$} & En fazla riskli & 3 & 15,8 & 12 & 63,2 & $\overline{---}$ & $\overline{---}$ & 4 & 21,1 & $\overline{---}$ & $\overline{---}$ & 19 & 3,8 & \multirow{5}{*}{4} & \multirow{5}{*}{4,403} & \multirow{5}{*}{$0,002 *$} \\
\hline & Orta riskli & 17 & 22,7 & 33 & 44,0 & 3 & 4,0 & 17 & 22,7 & 5 & 6,7 & 75 & 15,0 & & & \\
\hline & Az riskli & 34 & 19,0 & 75 & 41,9 & 20 & 11,2 & 45 & 25,1 & 5 & 2,8 & 179 & 35,8 & & & \\
\hline & Risk yok & 24 & 18,2 & 42 & 31,8 & 27 & 20,5 & 31 & 23,5 & 8 & 6,1 & 132 & 26,4 & & & \\
\hline & Fikrim yok & 24 & 25,3 & 37 & 38,9 & 4 & 4,2 & 21 & 22,1 & 9 & 9,5 & 95 & 19,0 & & & \\
\hline \multirow{5}{*}{ Trafik } & En fazla riskli & 34 & 23,4 & 54 & 37,2 & 15 & 10,3 & 36 & 24,8 & 6 & 4,1 & 145 & 29,1 & & & \\
\hline & Orta riskli & 43 & 29,7 & 55 & 37,9 & 14 & 9,7 & 25 & 17,2 & 8 & 5,5 & 145 & 28,9 & & & \\
\hline & Az riskli & 13 & 12,0 & 47 & 43,5 & 17 & 15,7 & 26 & 24,1 & 5 & 4,6 & 108 & 21,6 & 4 & 2,379 & 0,051 \\
\hline & Risk yok & 8 & 13,3 & 25 & 41,7 & 8 & 13,3 & 16 & 26,7 & 3 & 5,0 & 60 & 12,0 & & & \\
\hline & Fikrim yok & 4 & 9,5 & 18 & 42,0 & --- & --- & 15 & 35,7 & 5 & 11,9 & 42 & 8,4 & & & \\
\hline & En fazla riskli & 3 & 16,7 & 5 & 27,8 & 1 & 5,6 & 9 & 50,0 & --- & --- & 18 & 3,6 & & & \\
\hline & Orta riskli & 25 & 37,3 & 24 & 35,8 & 2 & 3,0 & 11 & 16,4 & 5 & 7,5 & 67 & $\begin{array}{l}13,4 \\
13,4\end{array}$ & & & \\
\hline Terör & Az riskli & 18 & 14,2 & 63 & 49,6 & 13 & 10,2 & 30 & 23,6 & 3 & 2,4 & 127 & 25,4 & 4 & 3,891 & $0,004 *$ \\
\hline & Risk yok & 34 & 19,5 & 66 & 37,9 & 35 & 20,1 & 31 & 17,8 & 8 & 4,6 & 174 & 34,8 & & & \\
\hline & Fikrim yok & 22 & 19,3 & 41 & 36,0 & 3 & 2,6 & 37 & 32,5 & 11 & 9,6 & 114 & 22,8 & & & \\
\hline
\end{tabular}

Tablo. 4 Turistlerin Cinsel Tacize, Hırsızlı̆̆a, Suça, Kap-Kaç, Trafik ve Terör Olaylarına Maruz Kalmaları Durumunda Risk Algılarının Dă̆ılımı

\section{Sonuç}

Çalışmanın bulgularına göre, farklı ülkelerden Alanya'yı ziyarete gelen turistlerin çok büyük bir oranının $(\% 90,6)$ Alanya'yı güvenli buldukları görülmektedir. Ülke gruplarına göre incelendiğinde Alanya’yı diğer ülke gruplarına göre en güvenli bulanlar Kuzey Avrupa ülkelerinden gelen turistlerdir. Ancak Kuzey Avrupa ülkelerinden gelen turistlerin kendi yaşadıkları kentin Alanya'dan daha güvenli olduklarını vurgulamaktadırlar. Doğu Avrupa ülkelerinden gelen turistler kendi kent/ülkeleriyle karşılaştırmaları istendiğinde ise diğer ülke gruplarına göre Alanya'nın daha güvenli bir kent olduğunu ifade etmişlerdir (\%47,3). Yine belirgin bir farklılık, güvenlik hizmetlerinden duyulan memnuniyete ilişkindir. Doğu Avrupa ülkelerinden gelen turistler diğer ülke gruplarına göre yüksek bir oranda güvenlik hizmetlerinden (\%40.6) memnun oldukları görülmektedir.

Turistlerin toplu taşıma araçlarında ve gece ve gündüz yaya olarak dışarı çıktıkları durumlarda gelinen ülke grubu ile güvenlik algıları arasında bir ilişki olduğu belirlenmiştir. Kuzey Avrupa ülkelerinden gelen turistler, toplu taşıma araçlarında diğer ülke gruplarına göre kendilerini daha güvende $(\% 34,5)$ hissetmektedirler. Diğer durumlarda da ülke gruplarına göre benzer bir dağılım söz konusu olduğu görülmektedir.

Genel olarak turistlerin en yüksek risk algıladıkları durumun trafik sorunu (\%80) olduğu diğer bulgular arasındadır. Ülke gruplarına göre turistlerin hırsızlık, kap-kaç, cinsel taciz, kriminal suçlar ve terör gibi risk 
algısını etkileyen faktörler bakımından farklı seviyelerde risk algılarının olduğu göze çarpmaktadır. Örneğin hırsızlık konusunda Doğu Avrupa'dan gelen turistlerin daha yüksek düzeyde risk algılarının olduğu tespit edilmiştir. t-testi sonuçlarına göre kap-kaç riski konusunda Orta Avrupa, Batı Avrupa ve Kuzey Avrupa ülkelerinden gelen turistlerden farklılaşmaktadır ve daha yüksek kap-kaç riski algılamaktadırlar. Ülke gruplarının risk algılarının ortalamaları incelendiğinde Doğu Avrupa'dan gelen turistlerin cinsel taciz konusunda daha yüksek risk algısına sahip oldukları görülmektedir. Kriminal suç ve terör riski açısından ise Kuzey Avrupa, Orta Avrupa ve Batı Avrupa ülkelerinden daha yüksek daha yüksek risk algılamaktadırlar.

Uluslararası literatürde daha önce yapılan çalışmaları teyit eden bulgulara ulaşan araştırma, gelinen ülke grubu ile algılanan risk arasındaki ilişkiyi ortaya koymuştur. Gerçekten de risk algısını etkileyen faktörler açısından ve Alanya'da günlük yaşamın devam ettiği ortamlar bakımından ülke gruplarına göre farklı seviyelerde göze çarpan bir farklılık söz konusudur. Bu bağlamda, ülke gruplarına göre farklı düzeylerde ortaya çıkan algı farklılığının nedenlerinin belirlenmesi; özel ve kamusal güvenlik hizmeti sağlayıcılarının, destinasyon yönetiminin ve diğer paydaşların risk algılarını minimize edecek nitelikte turizm planlama, pazarlama ve reklam stratejilerini oluşturması, destinasyon imajı açısından hayati bir öneme sahiptir.

\section{Kaynakça}

- Anuar, A.N.A., S. N. Bookhari ve N. A. Aziz, 2010. "The effectiveness of Safe City Programme as Safety Basic in the Tourism Industry: Case Study in Putrajaya", Procedia-Social and Behavioral Sciences, 42, 477 485.

- Barker, M. ve S. J. Page, 2002. "Visitor Safety in Urban Tourism Environments: The Case of Auckland, New Zealand", Cities, 19(4), 273-282.

- $\quad$ Batra, A., 2008. "Foreign Tourists' Perception towards Personal Safety and Potential Crime While Visiting Bangkok", Anatolia: An International Journal of Tourism and Hospitality Research, 19(1), 89-101.

- Cavlek, N., 2002. "Tour Operators and Destination Safety”, Annals of Tourism Research, 29(2), 478-496.

- Çetinsöz, B. C. ve Z. Ege, 2013. "Impacts of Perceived Risks on Tourists' Revisit Intentions”, Anatolia: An International Journal of Tourism and Hospitality Research, 24(2), 173-187

- Chang, H. H., 2011. "Nationality's Differences in Youth Tourists' Travelling Risk Perceptions and Satisfactions within Taiwan", Journal of Tourism, XI (2), 19-50.

- Dimanche, F. ve A. Lepetic, 1999. "New Orleans Tourism and Crime: A Case Study", Journal of Travel Research, August, 38, 19-23.

- Donaldson, R. ve S. Ferreira, 2009. “(Re-) Creating Urban Destination Image: Opinions of Foreign Visitors to South Africa on Safety and Security", Urban Forum, 20(1), 1-18.

- Elliot, L. ve C. Ryan, 1993. "The Impact of Crime on Corsican Tourism: A Descriptive Assessment", World Travel and Tourism Review, 3, 287-293.

- Ferreira, S. ve A. Harmse, 2000. "Crime and Tourism in South Africa: International Tourists' Perceptions and Risk”, South Africa Geographical Journal, 82(2), 80-85.

- Flicker, M. H. ve M. P. Gardner, 2002. "Which is Scarier: the Mall of the Mail?", Paper Presented at the Direct Marketing Education Foundation Annual Conference, San Francisco, CA.

- George, R. ve I. Booyens, 2014. "Township Tourism Demand: Tourists' Perceptions of Safety and Security", Urban Forum, 25(4), December, 449-467.

- George, R., 2003. "Tourists' Perceptions of Safety and Security While Visiting Cape Town", Tourism Management, 24(5), 575-585.

- Glaesser, D., 2003. "Crises' Spheres of Activity. Crisis Management in the Tourism Industry", Burlington, MA: Elsevier Butterworth-Heinemann.

- Irvine, W. ve A. R. Anderson, 2006. "The Effect of Disaster on Peripheral Tourism Places and the Disaffection of Prospective Visitors", in Y. Mansfeld ve A. Pizam (Eds.), Tourism, Security \& Safety: From Theory to Practice, Oxford: Butterworth-Heinemann, 169-186.

- Iverson, T. J., 1997. "Decision Timing: A Comparison of Korean and Japanese Travelers", International Journal of Hospitality Management, 16(2), 209-219.

- Kelly, I., 1993. "Tourist Destination Crime Rates: An Examination of Cairns and the Gold Coast, Australia", Journal of Tourism Studies, 4(2), 2-11.

- Kovari, I., ve K. Zimanyi, 2011. "Safety and Security in the Age of Global Tourism (The Changing Role and Conception of Safety and Security in Tourism)", APSTRACT: Applied Studies in Agribusiness and Commerce, 5, 59-61.

- Laws, E. ve B. Prideaux, 2005. "Crisis Management: A Suggested Typology", Journal of Travel and Tourism Marketing, 19(2/3), 1-8.

- $\quad$ Lepp, A. ve H. Gibson, 2003. "Tourist Roles, Perceived Risk and International Tourism”, Annals of Tourism Research, 30(3), 606-624.

- Levantis, T. ve A. Gani, 2000. "Tourism Demand and the Nuisance of Crime", International Journal of Social Economics, 27(7/8/9/10), 959-967. 
- March, R. ve A. G. Woodside, 2005. "Tourism Behavior: Travellers' Decisions and Actions, Oxon, UK: CABI.

- Maser, B. ve K. Weiermair, 1998. "Travel Decision-Making: From the Vantage Point of Perceived Risk and Information Preferences, Journal of Travel \& Tourism Marketing, 7 (4), 107-121.

- Mawby, R. L., 2000. "Tourists' Perceptions of Security: The Risk-Fear Paradox", Tourism Economics, 6(2), 109-121.

- Mitchell, V. W. ve V. Vasso, 1997. "Perceived Risk and Risk Reductions in Holiday Purchase: A CrossCultural and Gender Analysis, Journal of Euromarketing, 6(3), 47-97.

- Moutinho, L., 2000. "Consumer Behavior in Tourism", in L. Moutinho (Ed.), Strategic Management in Tourism, New York: CABI.

- Pelfrey, W. V., 1998. "Tourism and Crime: A Preliminary Assessment of the Relationship of Crime to the Number of Visitors at Selected Sites", International Journal of Comparative and Applied Criminal Justice, 22(2), 293-304.

- Pinhey, T. K. ve T. J. Iverson, 1994. "Safety Concerns of Japanese Visitors to Guam”, Journal of Travel and Tourism Marketing, 3(2), 87-94.

- Pizam, A. ve Y. Mansfeld, 2006. "Toward A Theory of Tourism Security", in Y. Mansfeld ve A. Pizam (Eds.), Tourism, security \& Safety: From Theory to Practice, Oxford: Butterworth-Heinemann, 1-27.

- Pizam, A., A. Reichel ve N. Uriely, 2002. "Sensation Seeking and Tourist Behavior", Journal of Hospitality \& Leisure Marketing, 9(2), 17-33.

- Pizam, A. ve Y. Mansfeld, 1996. "Introduction”, in A. Pizam ve Y. Mansfeld (Eds.), Tourism, Crime and International Security Issues, Chichester: John Wiley \& Sons, 1-7.

- Prideaux, B. ve A. Dunn, 1995. "Tourism and Crime: How Can the Tourism Industry Respond? The Gold Coast Experience", Australian Journal of Hospitality Management, 2 (1), 7-15.

- Qi, C. X., H. J. Gibson ve J. J. Zhang, 2009. "Perceptions of Risk and Travel Intentions: The Case of China and the Beijing Olympic Games", Journal of Sport and Tourism, 14 (1), 43-67.

- Reisinger Y. ve F. Mavondo, 2005. "Travel Anxiety and Intentions to Travel Internationally: Implications of Travel Risk Perception", Journal of Travel Research, 43 (3), 212-225.

- Richardson, S. ve J. Crompton, 1988. "Vacation Patterns of French and English Canadians", Annals of Tourism Research, 15(3), 430-545.

- Rittichainuwat B. N. ve G. Chakraborty, 2009. "Perceived Travel Risks Regarding Terrorism and Disease: The Case of Thailand", Tourism Management, 30(3), 410-418.

- Roehl, W. S., ve D. R. Fesenmaier, 1992. "Risk Perceptions and Pleasure Travel: An Exploratory Analysis", Journal of Travel Research, 30(4), 17-26.

- Ryan, C., 1993. “Crime, Violence, Terrorism and Tourism, An Accidental or Intrinsic Relationship?”, Tourism Management, 14, 173-183.

- Sirakaya, E. ve A. G. Woodside, 2005. "Building and Testing Theories of Decision Making by Travelers", Tour Manage, 26(6): 815-832.

- Sirakaya, E., A. G. Sheppard ve R. W. McLellan, 1997. “Assessment of the Relationship Between Perceived Safety at A Vacation Site and Destination Choice Decisions: Extending the Behavioral Decision-Making Model", Journal of Hospitality \& Tourism Research, 21(2), 1-10.

- Sönmez, S. F. ve A. R. Graefe, 1998a. "Influence of Terrorism Risk on Foreign Tourism Decisions", Annals of Tourism Research, 25 (1), 112-144.

- Sönmez, S. F. ve A. R. Graefe, 1998b. "Determining Future Travel Behavior from Past Travel Experience and Perceptions of Risk and Safety", Journal of Travel Research, 37(2), 171-177.

- Tarlow, P., 2000. "Creating Safe and Secure Communities in Economically Challenging Times", Tourism Economics, 6(2), 139-149.

- Yavaş, U., 1987. "Foreign Travel Behavior in A Growing Vacation Market: Implications for Tourism Marketers”, European Journal of Marketing, 21(5), 57-69. 